\title{
РОЛЬ ОКСИДАТИВНОГО СТРЕСУ В ПАТОГЕНЕЗІ ХРОНІЧНОГО ЕНТЕРОКОЛІТУ НА ФОНІ ЕКСПЕРИМЕНТАЛЬНОГО СТРЕПТОЗОТОЦИНОВОГО ДІАБЕТУ
}

Вступ. У медичній літературі є достатня кількість публікацій про взаємозв'язок між запальними захворюваннями кишечника, колоректальним раком і цукровим діабетом 2 типу поряд із запаленням та дисбактеріозом. Існуючі дані дозволяють стверджувати, що, з одного боку, діабет є вагомим фрактором у патогенезі захворювань кишечника, а з іншого - хронічні захворювання кишечника асоціюються із цукровим діабетом.

Мета дослідження - оцінити зміни окиснювальних процесів у сироватці крові й тканинах тонкої кишки щурів при розвитку хронічного ентероколіту на фоні цукрового діабету, викликаного стрептозотоцином, за показником окисної модифрікації білків.

Методи дослідження. Дослідження проведено на 106 білих нелінійних щурах-самцях. Цукровий діабет (стрептозотоциновий діабет - СТД) моделювали шляхом однократного внутрішньочеревного введення стрептозотоцину. Хронічний ентероколіт (ХЕК) було відтворено шляхом вільного доступу до тварин 1,0 \% розчину каррагінану в питній воді протягом 1 місячя. Ступінь окисної модифрікації білків визначали методом, який полягає в утворенні альдегіднихікетонних груп, що взаємодіють із 2,4-динітросренілгідразином з утворенням 2,4-динітрофенілгідразонів.

Результати й обговорення. За результатами власних досліджень доведено, що вміст кетонопохідних нейтрального характеру, що реєструються при довжині хвилі 370 нм, перевищував контрольні значення у 2-й і 3-й дослідних групах на 7,5\% (p<0,05), в 4-й - на 15,0\% (p<0,01). Рівень у сироватці крові окисномодифрікованих білків (ОМБ) основного характеру, що реєструються при довжині хвилі 430 нм, статистично значимо зростав: при СТД - на 91,6 \%, при ХЕК - на 64,5 \%, при їх поєднанні - на 166,9 \%. У тканинах тонкої кишки концентрація ОМБ контролю: у 2-й і 3-й групах - на 26,8 \%, у 4-й - на 82,1 \% (p<0,01). Вміст альдегідопохідних основного характеру, що реєструються при довжині хвилі 430 нм, підвищувався як при СТД, так і при ХЕК - у середньому на 46,0 \%, тоді як при ХЕК на фроні СТД - на 151,4 \%.

Висновок. За умови хронічного ентероколіту на фроні цукрового діабету підвищується окисна модифрікація білків, яка характеризується зростанням аліфратичних альдегідо- і кетондинітрофренілгідразонів нейтрального та основного характеру в сироватці крові й тканинах тонкої кишки з переважанням явищ фррагментації білків $(p<0,05)$.

КЛЮчОВІ СЛОВА: стрептозотоциновий діабет; хронічний ентероколіт; окисна модифрікація білків; експеримент.

ВСТУП. Станом на 2015 р. понад 415 мільйонів дорослих осіб хворіли на цукровий діабет, і це число, за оцінками експертів зі всього світу, зросте до 642 мільйонів до 2040 р. [18]. Розуміння патогенезу цукрового діабету є надзвичайно важливим у фрормуванні загальної стратегії профрілактики і лікування цього захворювання [13]. На даний час відомо, що в пацієнтів із цукровим діабетом у 5 разів більший ризик смерті [12]. Діабет спричиняє серцево-судинну патоло(c) Н. В. Ліснянська, 2017. гію, сліпоту, нетравматичні ампутації нижніх кінцівок, ниркову недостатність $[15,17]$. У ряді робіт зазначено, що він асоціюється як фрактор ризику для захворювань порожнини рота [10, 21]. У медичній літературі $€$ достатня кількість публікацій про взаємозв'язок між запальними захворюваннями кишечника, колоректальним раком і цукровим діабетом 2 типу поряд із запаленням та дисбактеріозом [11, 14, 16, 23, 24]. Існуючі дані дозволяють стверджувати, що, 3 одного боку, діабет є вагомим фрактором у пато- 
генезі захворювань кишечника, а з іншого - хронічні захворювання кишечника асоціюються із цукровим діабетом.

Мета дослідження - оцінити зміни окиснювальних процесів у сироватці крові й тканинах тонкої кишки щурів при розвитку хронічного ентероколіту на фроні цукрового діабету, викликаного стрептозотоцином, за показником окисної модисрікації білків.

МЕТОДИ ДОСЛІДЖЕННЯ. Дослідження проведено на 106 білих нелінійних щурах-самцях, яких утримували на стандартному раціоні віварію Тернопільського державного медичного університету імені І. Я. Горбачевського. Під час роботи дотримувалися принципів Європейської конвенції про захист хребетних тварин, що використовуються для дослідних та інших наукових цілей (Страсбург, 1986). Піддослідних щурів поділили на чотири групи: 1-ша - контроль (інтактні тварини); 2-га - тварини із цукровим діабетом; 3-тя тварини із хронічним ентероколітом (ХЕК); 4-татварини із хронічним ентероколітом на фоні цукровогодіабету. Цукровийдіабет (стрептозотоциновий діабет - СТД) моделювали шляхом однократного внутрішньочеревного введення тваринам віком 2 місяці стрептозотоцину ("Sigma Aldrich", США) в дозі 60 мг/кг маси тіла [19]. Безпосередньо перед введенням стрептозотоцин розчиняли в 0,1 молярному цитратному буфері (рH 4,5). Щурам контрольної групи вводили відповідну кількість цитратного бусрера. В експерименті використовували тварин з рівнем глюкози не нижче 10,8 ммоль/л через 2 тижні після введення стрептозотоцину. Хронічний ентероколіт було відтворено шляхом вільного доступу до щурів 1,0 \% розчину каррагінану в питній воді протягом 1 місяця [5, 20]. У 4-й дослідній групі тваринам із СТД (через 2 тижні після введення стрептозотоцину) моделювали ХЕК протягом 1 місяця. Евтаназію щурів проводили шляхом пункції серця під глибокою анестезією відповідно до вимог Комітету з догляду за тваринами [7].

Ступінь окисної модифікації білків визначали методом [3], який полягає в утворенні альдегідних і кетонних груп, що взаємодіють із 2,4-динітрофренілгідразином з утворенням 2,4-динітрофренілгідразонів. Альдегідо- і кетонопохідні нейтрального характеру реєстрували спектрофоотометрично при довжині хвилі 370 нм, а основного - при 430 нм. Паралельно в плазмі крові й гомогенаті тонкої кишки визначали білки. Вміст френілгідразонів розраховували, використовуючи коефіцієнт молярної екстинкції $2,1 \times 10^{4}$ моль ${ }^{-1} \mathrm{CM}^{-1}$.

Отримані дані піддавали статистичній обробці $[2,6]$. Для перевірки на відповідність вибірок даних нормальному закону розподілу було застосовано розрахунок критерію ШапіроУїлка. У зв'язку з відсутністю відповідності даних нормальному розподілу на рівні значимості p<0,05 обчислювали середньовибіркові характеристики: медіану (Мe), перший і третій квартилі (Q25-Q75). Рівень статистичної значущості відмінностей вибірок оцінювали за допомогою непараметричного критерію Манна-Уїтні. Відмінності вважали статистично значущими при досягнутому рівні $p<0,05$.

РЕЗУЛЬТАТИ Й ОБГОВОРЕННЯ. У реЗУЛЬтаті окисної модисрікації білків змінюються структура, фрізико-хімічні та біологічні властивості білкової молекули. Це вважають раннім і найбільш надійним індикатором оксидативного стресу [9]. Вивчення карбонільних продуктів окиснення білків сироватки крові щурів із СТД, ХЕК та їх поєднанням показало наявність альдегідо- і кетондинітрофенілгідразонів нейтрального й основного характеру. За результатами власних досліджень доведено, що вміст аліфратичних кетондинітрофенілгідразонів нейтрального характеру, що реєструються при довжині хвилі 370 нм, перевищував контрольні значення у 2-й і 3-й дослідних групах на 7,5 \% (p<0,05), в 4-й на $15,0 \%(p<0,01)$. Рівень у сироватці крові окисномодифікованих білків (ОМБ) основного характеру, що реєструються при довжині хвилі 430 нм, статистично значимо зростав: при СТДна 91,6 \%, при ХЕК - на 64,5 \%, при їх поєднанні - на 166,9 \% (табл. ). У тканинах тонкої кишки концентрація $\mathrm{OMБ}_{370}$ також збільшувалась у всіх дослідних групах стосовно контролю, зокрема, у 2-й і 3-й групах - на 26,8 \%, у 4-й - на 82,1 \% ( $<<0,01)$. Вміст альдегідодинітрофенілгідразонів основного характеру, що реєструються при довжині хвилі 430 нм, підвищувався як при СТД, так і при XЕК - у середньому на 46,0 \%, тоді як при ХЕК на фроні СТД - на 151,4 \%.

Порівнюючи отримані в сироватці крові й тканинах тонкої кишки результати, можна стверджувати, що при СТД та ХЕК підвищувалась окисна модифрікація білків, проте найбільший вміст ОМБ виявлено при хронічному ентероколіті на фроні стрептозотоцинового діабету. Слід зазначити, що вміст аліфатичних альдегідодинітросренілгідразонів основного характеру, що реєструються при довжині хвилі 430 нм, перевищував значення кетонопохідних нейтрального характеру з максимальною різницею при ХЕК на фроні СТД (рис.).

Відомо, що високореакційні активні метаболіти оксигену викликають окиснення молекул, ініціюють ланцюгові реакції в мембранах ліпідів та окисну модифрікацію нуклеїнових кислот і 
Таблиця - Показники інтенсивності окисної модифрікації білків у сироватці крові й тканинах тонкої кишки при хронічному ентероколіті на фоні цукрового діабету, Ме (Q25-Q75)

\begin{tabular}{|c|c|c|c|c|}
\hline \multirow{3}{*}{ Показник } & \multicolumn{4}{|c|}{ Група тварин } \\
\hline & $\begin{array}{c}\text { контроль } \\
\text { (1-ша група) }\end{array}$ & $\begin{array}{c}\text { цукровий діабет } \\
\text { (2-га група) }\end{array}$ & $\begin{array}{c}\text { хронічний } \\
\text { ентероколіт } \\
\text { (3-тя група) }\end{array}$ & $\begin{array}{c}\text { цукровий діабет+ } \\
\text { хронічний ентероколіт } \\
\text { (4-та група) }\end{array}$ \\
\hline & \multicolumn{4}{|c|}{ сироватка крові } \\
\hline ОМБ $_{370}$, мкмоль/мг білка & $\begin{array}{c}0,80 \\
{[0,76 ; 0,85]} \\
\end{array}$ & $\begin{array}{c}0,86^{*} \\
{[0,84 ; 0,90]}\end{array}$ & $\begin{array}{c}0,86^{*} \\
{[0,82 ; 0,90]} \\
\end{array}$ & $\begin{array}{c}0,92^{*} \\
{[0,89 ; 0,96]}\end{array}$ \\
\hline \multirow[t]{2}{*}{ ОМБ $_{430}$, мкмоль/мг білка } & $\begin{array}{c}3,44 \\
{[3,22 ; 3,57]}\end{array}$ & $\begin{array}{c}6,59^{*} \\
{[6,57 ; 6,98]}\end{array}$ & $\begin{array}{c}5,66^{*} \\
{[5,29 ; 5,95]}\end{array}$ & $\begin{array}{c}9,18^{*} \\
{[9,03 ; 9,26]}\end{array}$ \\
\hline & \multicolumn{4}{|c|}{ тканини тонкої кишки } \\
\hline ОМБ $_{370}$, мкмоль/мг білка & $\begin{array}{c}0,56 \\
{[0,52 ; 0,57]}\end{array}$ & $\begin{array}{c}0,71^{*} \\
{[0,68 ; 0,73]}\end{array}$ & $\begin{array}{c}0,71^{*} \\
{[0,68 ; 0,73]}\end{array}$ & $\begin{array}{c}1,02^{\star} \\
{[0,96 ; 1,11]}\end{array}$ \\
\hline ОМБ $_{430}$, мкмоль/мг білка & $\begin{array}{c}2,80 \\
{[2,67 ; 2,97]}\end{array}$ & $\begin{array}{c}4,09^{*} \\
{[3,94 ; 4,30]}\end{array}$ & $\begin{array}{c}4,03^{\star} \\
{[3,77 ; 4,23]}\end{array}$ & $\begin{array}{c}7,04^{*} \\
{[6,92 ; 7,20]}\end{array}$ \\
\hline
\end{tabular}

Примітка. * - достовірна відмінність стосовно контролю.
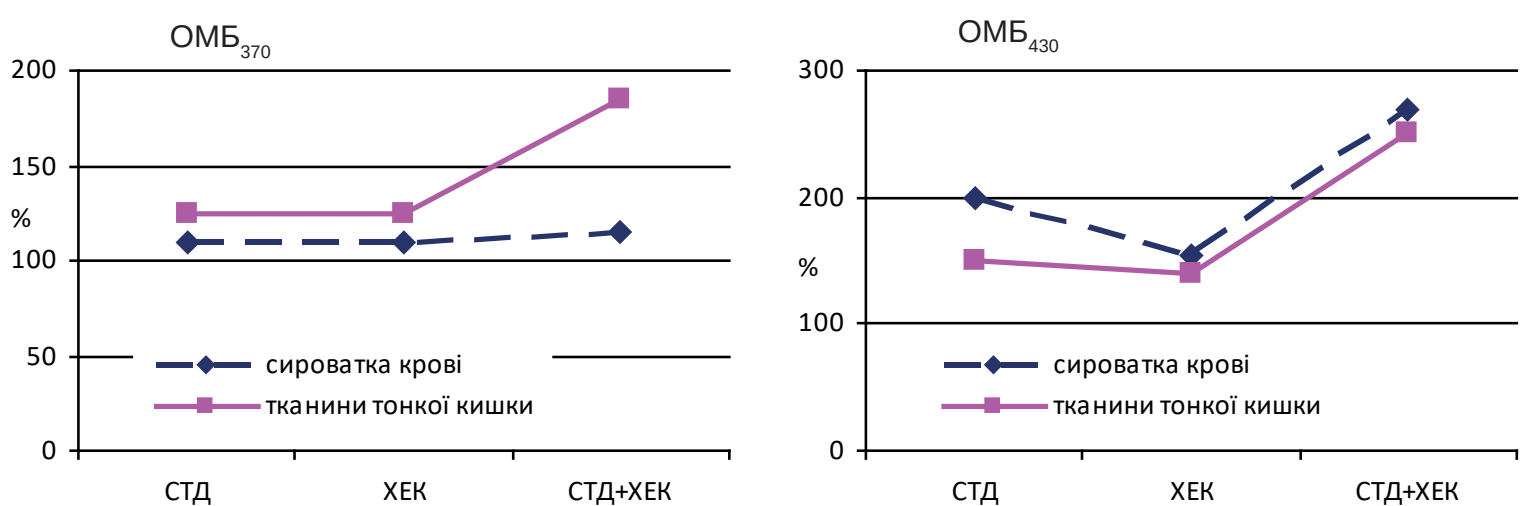

Рис. Динаміка змін окисної модифікації білків у крові й тканинах тонкої кишки при хронічному ентероколіті на фроні цукрового діабету.

білків, що призводить до втрати їх біологічної активності $[1,8]$. Доведено, що при цукровому діабеті зростання окисної модисрікації білків сприяє появі нових антигенів, провокуючи імунну відповідь, що відіграє значну роль у патогенезі й розвитку ускладнень при цукровому діабеті [4].

Ураження тканин тонкої кишки теж пов'язане 3 гіперпродукуванням вільних радикалів, більшість дослідників вказує на роль нітрооксидативного стресу в патогенезі хронічного ентероколіту [22]. При цьому максимальні зміни ОМБ реєструють при розвитку хронічного ентероколіту на фроні цукрового діабету. Очевидно, вільнорадикальні процеси, які характерні для обидвох досліджуваних патологій, при поєднанні захворювань сумуються, потенціюючи дію кожного. Отже, ОМБ є важливою ланкою у ланцюгу патобіохімічних механізмів розвитку хронічного ентероколіту на фроні цукрового діабету.
Важливим наслідком дії активних фрорм оксигенуна білкиєпорушення нативної конформації білків з утворенням великих білкових агрегатів або фррагментація білкової молекули, що в будьякому випадку призводить до інактивації фрерментів. Відомо, що кетонопохідні розглядають як маркери процесів агрегації, а альдегідопохідніяк маркери фррагментації білків. У дослідженні встановлено, що при всіх експериментальних моделях явища фррагментації перевищували процеси агрегації білків.

ВИСНОВОК. За умови хронічного ентероколіту на фроні цукрового діабету підвищується окисна модифікація білків, яка характеризується зростанням аліфатичних альдегідо- і кетондинітрофренілгідразонів нейтрального та основного характеру в сироватці крові й тканинах тонкої кишки з переважанням явищ оррагментації білків $(p<0,05)$. 


\section{СПИСОК ЛІТЕРАТУРИ}

1. Гембаровський М. В. Вплив харчової депривації на показники пероксидного окиснення ліпідів та системи антиоксидантного захисту печінки щурів / М.В.Гембаровський, І. М. Кліщ, М. І. Марущак // Мед. хімія. - 2013. - 15, № 1 (54). - С. 25-29.

2. Гланц С. Медико-биологическая статистика / С. Гланц ; пер. $з$ англ. - М. : Практика, 1999. - 459 с.

3. МещишенІ. Ф. Методвизначення окислювальної модифрікації білків плазми (сироватки) крові / І. Ф. Мещишен // Буковин. мед. вісн. - 1998. - № 1. - С. 156158.

4. Окислительная модисрикация белков и система глутатиона в адипоцитах при сахарном диабете / Е. В. Шахристова, Е. А. Степовая, В. В. Иванов [и др.] // Бюл. сибир. медицины. - 2014. - 13, № 3. - С. 84-90.

5. Пат. 97322 Україна, МПК: G09B 23/28. Спосіб моделювання хронічного гастроентероколіту / Губіна-Вакулик Г. І., Колоусова Н. Г., Іваненко Т. О., Горбач Т. В., Коробчанський В. О. ; заявник і патентовласник Харк. нац. мед. ун-т. - № а201014510 ; заявл. 06.12.10 ; опубл. 25.01.12, Бюл. № 2.

6. Реброва О. Ю. Статистический анализ медицинских данных. Применение пакета прикладных программ STATISTICA / О. Ю. Реброва. - М. : МедиаCopepa, 2002. - 312 c.

7. Резніков О. Загальні етичні принципи експериментів на тваринах / О. Резніков // Endokrynolohiya. 2003. - 8 (1). - P. 142-145.

8. Супрун Э. В. Эфрфекты окислительной модифрикации белков и фрормирование неврологических дисорункций при экспериментальном ишемическом инсульте на фооне коррекции ронколейкином / Э. В. Супрун // Укр. журн. екстремал. медицини імені Г. О. Можаєва. - 2011. - 12, № 3. - С. 87-94.

9. Шевелькова А. А. Окислительная модисрикация белков и содержание тиолов в крови при физиологически протекающей беременности / А. А. Шевелькова, А. В. Вьюшина // Журн. акушерства и женских болезней. - 2012. - LXI, вип. 4. - С. 109-112.

10. Update on diabetes mellitus and related oral diseases / M. Manfredi, M. J. McCullough, P. Vescovi [et al.] // Oral Diseases. - 2004. - 10, №. 4. - P. 187-200.

11. Association among genetic predisposition, gut microbiota, and host immune response in the etiopathogenesis of inflammatory bowel disease / P. J. Basso, M. T. C. Fonseca, G. Bonfá [et al.] // Braz. J. Med. Biol. Res. - 2014. - 47. - P. 727-737.

12. Cause-specific mortality in a population with diabetes: South Tees Diabetes Mortality Study / N. A. Roper, R. W. Bilous, W. F. Kelly [et al.] // Diabetes Care. - 2002. - № 25. - P. 43-48.

\section{REFERENCES}

1. Hembarovskyi, M.V., Klishch, I.M., \& Marushchak, M.I. (2013). Vplyv kharchovoi depryvatsii na pokaznyky peroksydnoho okysnennia lipidiv ta systemy antyoksydantnoho zahystu pechinky shchuriv [Effect of food deprivation on parameters of lipid peroxidation and
13. Diabetes in Europe: an update / T. Tamayo, J. Rosenbauer, S.H. Wild [et al.] // Diabetes Res. Clin. Pract. - 2014. - № 103. - P. 206-217.

14. Dismicrobism in inflammatory bowel disease and colorectal cancer: changes in response of colocytes / G. Tomasello, P. Tralongo, P. Damiani [et al.] // World J. Gastroenterol. -2014. - № 28; 20 (48). -P. 18121-18130. doi: 10.3748/wjg.v20.i48.18121.

15. Epidemiology of diabetes and complications among adults in the Republic of Ireland 1998-2015: a systematic review and meta-analysis / M. L. Tracey, M. Gilmartin, K. O'Neill [et al.] // BMC Public Health. 2016. - № 16 (1). - P. 132.

16. Fischbach $S$. The role of TGF- $\beta$ signaling in $\beta$-cell dysfunction and type 2 diabetes: a review/S. Fischbach, G. K. Gittes // J. Cytol. Histol. - 2014. - № 5. - P. 282. doi:10.4172/2157-7099.1000282.

17. IDF Diabetes Atlas, 6th edn. [Electronic resource] / International Diabetes Federation. - Brussels, Belgium: 2013. - Access mode: http://www.idf.org/idfdiabetes-atlas-seventh-edition(2013).

18. IDF Diabetes Atlas, seventh edition 2015 [Electronic resource] / International Diabetes Federation. 2015. - Access mode: http://www.idf.org/idf-diabetesatlas-seventh-edition(2015).

19. Indomethacin inhibits thymic involution in mice with streptozotocin-induced diabetes / V. L. Ordodi, V. Paunescu, M. Ionac [et al.] // Artificial organs. -2008. 32 (1). - P. 66-70.

20. Moyana T. N. Carrageenan-induced intestinal injury in the rat a model for inflammatory bowel disease / T. N. Moyana, J. M. Lalonde // Ann. Clin. Lab. Sci. 1990. - 20 (6). - P. 420-426.

21. Negrato C. A. Buccal alterations in diabetes mellitus / C. A. Negrato, O. Tarzia // Diabetology and Metabolic Syndrome. - 2010. - 2. - P. 1-11.

22. Piechota-Polanczyk A. Review article: the role of oxidative stress in pathogenesis and treatment of inflammatory bowel diseases / Aleksandra PiechotaPolanczyk, Jakub Fichna // Naunyn-Schmiedeberg's Archives of Pharmacology. - 2014. - 387, Issue 7. P. 605-620.

23. Type 2 Diabetes and Cancer: What is the connection? Mount Sinai Journal of Medicine / D. Cannata, Y. Fierz, A. Vijayakumar, D. LeRoith // Mt. Sinai J. Med. - 2010. - № 77 (2). - P. 197-213. doi: 10.1002/ msj.20167.

24. Type 2 diabetes risk variants and colorectal cancer risk: the multiethnic cohort and PAGE studies / I. Cheng, C. P. Caberto, A. L. Jones [et al.] // Gut. -2011. № 60 (12). - P. 1703-1711.

antioxidant system of rat liver]. Medychna khimiia Medical Chemistry, 15, (1), 25-29 [in Ukrainian].

2. Glants, S. (1999). Mediko-biologicheskaya statistika [Biomedical statistics]. Moscow: Praktika [in Russian]. 
3. Meshchishen, I.F. (1998). Metod vyznachennia okysliuvalnoi modyfikatsii bilkiv plazmy (syrovatky) krovi [Method of determining the oxidative modification of plasma proteins (serum) blood]. Bukovyn. med. visnyk. Bukovyna Medical Journal, 1, 156-158 [in Ukrainian].

4. Shakhristova, E.V., Stepovaya, E.A., Ivanov, V.V., Nosareva, O.L., Ryazantseva, N.V., \& Novitskiy, V.V. (2014). Okislitelnaya modifikatsiya belkov i sistema glutationa v adipotsitah pri sakharnom diabete [Oxidative modification of proteins and glutathione system in adipocytes in diabetes mellitus]. Byulleten sibirskoy meditsiny - Bulletin of Siberian Medicine 13, (3), 84-90 [in Russian].

5. Hubina-Vakulik, H.I., Kolousova, N.H., Ivanenko, T.O., Horbach, T.V., Korobchanskyi, V.O. Sposib modeliuvannia khronichnoho hastroenterokolitu [The method of modeling of chronic gastroenterocolitis]. Patent Ukraina, № a201014510, 2012 [in Ukrainian].

6. Rebrova, O.Yu. (2002). Statisticheskiy analiz meditsinskikh dannykh. Primenenie paketa prikladnykh programm STATISTICA [Statistical analysis of medical data. Application of software package STATISTICA]. Moscow: MediaSfera [in Russian].

7. Reznikov, O. (2003). Zahalni etychni pryntsypy eksperymentiv na tvarynakh [The general ethical principles of experiments on animals]. Endokrynolohiia Endocrinology, 8 (1), 142-145 [in Ukrainian].

8. Suprun, E.V. (2011). Effekty okislitelnoy modifikatsii belkov i formirovanie nevrologicheskih disfunktsiy pri eksperimentalnom ishemicheskom insulte na fone korrektsii ronkoleykinom [Effects of oxidative modification of proteins and the formation of neurological dysfunctions in experimental ischemic stroke on the background of corneal treatment with Roncoleukin]. Ukrayinskyi zhurnal ekstremalnoi medytsyny imeni H. O. Mozhaeva Ukrainian Journal of Extracurricular Medicine by H. O. Mozhaiev, 12, (3), 87-94 [in Russian].

9. Shevelkova, A.A. (2012). Okislitelnaya modifikatsiya belkov i soderzhanie tiolov $v$ krovi pri fiziologicheski protekayushchey beremennosti [Oxidative modification of proteins and the content of thiols in the blood during a physiologically occurring pregnancy]. Zhurnal akusherstva i zhenskih bolezney - Journal of Obstetrics and Women's Diseases, LXI (4), 109-112 [in Russian].

10. Manfredi, M., McCullough, M.J., Vescovi, P., AlKaarawi, Z.M., \& Porter, S.R. (2004). Update on diabetes mellitus and related oral diseases. Oral Diseases, 10 (4), 187-200.

11. Basso, P.J., Fonseca, M.T.C., Bonfá, G., Alves, V.B.F., Sales-Campos, H., ... Nardini, V. (2014). Association among genetic predisposition, gut microbio$\mathrm{ta}$, and host immune response in the etiopathogenesis of inflammatory bowel disease. Braz. J. Med. Biol. Res., 47, 727-737.
12. Roper, N.A., Bilous, R.W., Kelly, W.F., Unwin, N.C., \& Connolly, V.M. (2002). Cause-specific mortality in a population with diabetes: South Tees Diabetes Mortality Study. Diabetes Care, 25, 43-48.

13. Tamayo, T, Rosenbauer, J, Wild, S.H., Spijkerman, A.M., Baan, C., ... Forouhi, N.G., (2014). Diabetes in Europe: an update. Diabetes Res. Clin. Pract., 103, 206-217.

14. Tomasello, G., Tralongo, P., Damiani, P., Sinagra, E., Trapani, B., ... Zeenny, M.N. (2014). Dismicrobism in inflammatory bowel disease and colorectal cancer: changes in response of colocytes. World J. Gastroenterol., 28, 20 (48), 18121-18130. doi: 10.3748/wjg.v20. i48.18121.

15. Tracey, M.L., Gilmartin, M., O'Neill, K., Fitzgerald, A.P., McHugh, S.M., ... Buckley, C.M., (2016). Epidemiology of diabetes and complications among adults in the Republic of Ireland 1998-2015: a systematic review and meta-analysis. BMC Public Health, 16 (1), 132.

16. Fischbach, S. (2014). The role of TGF- $\beta$ signaling in $\beta$-cell dysfunction and type 2 diabetes: a review. J. Cytol. Histol., 5, 282. doi:10.4172/2157-7099.1000282.

17. IDF Diabetes Atlas, 6th edn. International Diabetes Federation. (2013). www.idf.org. Access mode: http://www.idf.org/idf-diabetes-atlas-seventhedition(2013). Ionac [in Belgium].

18. IDF Diabetes Atlas, seventh edition 2015. International Diabetes Federation. (2015). www.idf.org. Access mode: http://www.idf.org/idf-diabetes-atlasseventh-edition(2015).multiethnic cohort and PAGE studies. Gut., 60 (12), 1703-1711.

19. Ordodi, V.L., Paunescu, V.L., \& Ionac M. (2008). Indomethacin inhibits thymic involution in mice with streptozotocin-induced diabetes. Artificial Organs., 32 (1), 66-70.

20. Moyana, T.N., \& Lalonde, J.M. (1990). Carrageenan-induced intestinal injury in the rat a model for inflammatory bowel disease. Ann. Clin. Lab. Sci., 20 (6), 420-426.

21. Negrato, C.A. (2010). Buccal alterations in diabetes mellitus. Diabetology and Metabolic Syndrome, 2 (3), 1-11.

22. Piechota-Polanczyk, Aleksandra, \& Fichna, Jakub (2014). Review article: the role of oxidative stress in pathogenesis and treatment of inflammatory bowel diseases. Naunyn-Schmiedeberg's Archives of Pharmacology, 387, (7), 605-620.

23. Cannata, D., Fierz, Y., Vijayakumar, A., \& LeRoith D. (2010). Type 2 Diabetes and Cancer: What is the Connection? Mount Sinai Journal of Medicine. Mt. Sinai J. Med., 77 (2), 197-213. doi: 10.1002/msj.20167.

24. Cheng, I., Caberto, C. P., Jones, A.L. (2011). Type 2 diabetes risk variants and colorectal cancer risk: the multiethnic cohort and PAGE studies. Gut., 60 (12), 1703-1711. 


\section{РОЛЬ ОКСИДАТИВНОГО СТРЕССА В ПАТОГЕНЕЗЕ ХРОНИЧЕСКОГО ЭНТЕРОКОЛИТА НА ФОНЕ ЭКСПЕРИМЕНТАЛЬНОГО СТРЕПТОЗОТОЦИНОВОГО ДИАБЕТА}

\section{Резюме}

Вступление. В медицинской литературе имеется достаточное количество публикаций о взаимосвязи между воспалительными заболеваниями кишечника, колоректальным раком и сахарным диабетом 2 типа наряду с воспалением и дисбактериозом. Существующие данные позволяют утверждать, что, с одной стороны, диабет является весомым фрактором в патогенезе заболеваний кишечника, а с другой хронические заболевания кишечника ассоциируются с сахарным диабетом.

Цель исследования - оценить изменения окислительных процессов в сыворотке крови и тканях тонкой кишки крыс при развитии хронического энтероколита на фоне сахарного диабета, вызванного стрептозотоцином, за показателем окислительной модификации белков.

Методы исследования. Исследование проведено на 106 белых нелинейных крысах-самцах. Сахарный диабет (стрептозотоциновый диабет - СТД) моделировали путем однократного внутрибрюшного введения стрептозотоцина. Хронический энтероколит (ХЭК) был воссоздан путем свободного доступа к животным 1,0\% раствора каррагинана в питьевой воде в течение 1 месяца. Степень окислительной модификации белков определяли методом, который заключается в образовании альдегидных и кетонных групп, взаимодействующих с 2,4-динитрофренилгидразином с образованием 2,4-динитрофренилгидразонов.

Результаты и обсуждение. По результатам собственных исследований доказано, что содержание кетонопроизводных нейтрального характера, регистрируемых при длине волны 370 нм, превышало контрольные значения во 2-й и 3-й опытных группах на 7,5 \% (p<0,05), в 4-й - на 15,0% (p<0,01). Уровень в сыворотке крови окислительномодифицированных белков (ОМБ) основного характера, регистрируемых при длине волны 430 нм, статистически значимо возрастал: при СТД - на 91,6 \%, при ХЭК - на 64,5\%, при их сочетании - на 166,9%. В тканях тонкой кишки концентрация ОМБ всех опытных группах относительно контроля: во 2-й и 3-й группах - на 26,8 \%, в 4-й - на 82,1 \% $(p<0,01)$. Содержание альдегидопроизводных основного характера, регистрируемых при длине волны 430 нм, повышалось как при СТД, так и при ХЭК - в среднем на 46,0 \%, тогда как при ХЭК на фооне СТД - на 151,4 \%.

Вывод. При хроническом энтероколите на фроне сахарного диабета повышается окислительная модифрикация белков, которая характеризуется возрастанием алифатических альдегидо- и кетондинитрофренилгидразонов нейтрального и основного характера в сыворотке крови и тканях тонкой кишки с преобладанием явлений фррагментации белков ( $p<0,05)$.

КЛЮЧЕВЫЕ СЛОВА: стрептозотоциновый диабет; хронический энтероколит; окислительная модисрикация белков; эксперимент.

N. V. Lisnianska

CHERNIVTSI MEDICAL COLLEGE OF BUKOVYNIAN STATE MEDICAL UNIVERSITY

\section{ROLE OF OXIDATIVE STRESS IN PATHOGENESIS OF CHRONIC ENTEROCOLITIS ON THE BACKGROUND OF STREPTOZOTOCIN-INDUCED DIABETES}

\section{Summary}

Introduction. In the medical literature there are a sufficient number of publications reporting on the relationship between inflammatory bowel disease, colorectal cancer and type 2 diabetes, together with inflammation and dysbiosis. Existing data suggest that, on the one hand, diabetes is an important factor in the pathogenesis of diseases of the intestine, and on the other hand, chronic bowel disease is associated with diabetes.

The aim of the study - to evaluate changes in oxidative processes in serum and small intestine tissues of rats with chronic enterocolitis on the background of streptozotocin-induced diabetes, in terms of oxidative modification of proteins. 
Materials and Methods. The study was conducted on 106 white male nonlinear-rats. Diabetes mellitus (streptozotocin diabetes STD) was modeled by a single intraperitoneal streptozotocin administration. Chronic enterocolitis (ChEC) was modeled by free access to animals in $1.0 \%$ carrageenan solution in water for 1 month. The degree of oxidative modification of proteins (OMP) was determined according to the formation of aldehyde and ketone groups during transformation 2.4 dinitrophenylhydrazine to the 2.4-dynitrofenilhidrazone.

Results and Discussion. The results of our research proved that neutral ketone derivatives content, recorded at a wavelength of $370 \mathrm{~nm}$, exceeding reference values of 2 and 3 experimental groups by $7.5 \%(p<0.05)$, and $4-$ by $15.0 \%$ ( $p<0.01)$. The level of alkaline oxidizing modified proteins in the serum, recorded at a wavelength of $430 \mathrm{~nm}$, statistically significantly increased in the STD in $91.6 \%$, in the ChEC in $64.5 \%$, and during combined pathology - in $166.9 \%$ (Table. 1). In the small intestine tissue concentration of $O M P_{370}$ also increased in all experimental groups regarding control, particularly in groups 2 and 3 in $26.8 \%$ in the $4-$ in $82.1 \%$ ( $p<0.01)$. Content of alkaline aldehyde derivatives content, recorded at a wavelength of $430 \mathrm{~nm}$, increased both in STD and ChEC with an average of $46.0 \%$, while in ChEC on the background of STD - in $151.4 \%$.

Conclusion. During chronic enterocolitis on the background of diabetes mellitus increases the oxidative modification of proteins, which is characterized by growth and aliphatic aldehyde and ketone derivatives with neutral and alkaline character in serum and small intestine tissues, with a predominance of protein fragmentation effects $(p<0.05)$.

KEY WORDS: streptozotocin-induced diabetes; chronic enterocolitis; oxidative modification of proteins; experiment.

Отримано 26.01.17

Адреса для листування: Н. В. Ліснянська, Чернівецький медичний коледж Буковинського державного медичного університету, вул. Героїв Майдану, 60, Чернівці, 58001, e-mail: sofnata@ukr.net. 